\title{
Buying behaviour of cotton growers with reference to cotton seed in middle Gujarat
}

\author{
RAVI SHANKAR*, Y.C. ZALA ${ }^{1}$ AND R.S. PUNDIR ${ }^{1}$ \\ Department of Agricultural Economics, B.A. College of Agriculture, Anand Agricultural University, ANAND \\ (GUJARAT) INDIA
}

\begin{abstract}
Present study was conducted in middle Gujarat for the estimation of buying behaviour of cotton growers of different size groups for the purchase of cotton seed. A multi-stage sampling design was applied for the study and required data were collected from 120 cotton growers ( 26 marginal, 19 small, 30 medium and 45 large) spread over 12 villages of 6 talukas, covering three cotton growing districts of the Middle Gujarat during 2011-12. The major methods employed for the analysis were linear multiple regression model and Garrett ranking technique. Brand loyalty among cotton seed growers were influenced by price of the seed, peer group influence, brand image, advertisement and availability of the seed. The most important constraint viewed by the cotton growers was non-availability of the branded seed demanded in desired quantity followed by non-availability of the branded seed in time.
\end{abstract}

Key Words : Cotton growers, Gossypium spp.

View Point Article : Shankar, Ravi, Zala, Y.C. and Pundir, R.S. (2016). Buying behaviour of cotton growers with reference to cotton seed in middle Gujarat. Internat. J. agric. Sci., 12 (2) : 265-270, DOI:10.15740/HAS/IJAS/12.2/265-270.

Article History : Received : 07.02.2016; Revised : 07.03.2016; Accepted : 30.04 .2016

\footnotetext{
* Author for correspondence:

${ }^{1}$ International Agribusiness Management Institute, Anand Agricultural University, ANAND (GUJARAT) INDIA
} 